\title{
A comparative review of intra-operative hemodynamic changes in patients undergoing vaginal surgeries using tumescent anaesthesia vs conventional techniques
}

\author{
Anu Pathak*, Saroj Singh, Manjari Goel, Neha Agrawal
}

Department of Obstetrics and Gynaecology, S.N. Medical College, Agra, India

Received: 22 June 2013

Accepted: 11 July 2013

\section{*Correspondence:}

Dr. Anu Pathak,

E-mail: dr.anupathak@ymail.com

(C) 2013 Pathak A et al. This is an open-access article distributed under the terms of the Creative Commons Attribution Non-Commercial License, which permits unrestricted non-commercial use, distribution, and reproduction in any medium, provided the original work is properly cited.

\begin{abstract}
Background: The objective was to assess intra-operative hemodynamic changes in patients undergoing vaginal surgeries using tumescent anaesthesia vs conventional techniques.

Methods: Study was carried out on 200 patients attending the Obst. \& Gynae. Dept. of S.N. Medical College, Agra. According to randomization they were divided into 2 groups: group-a: include 100 patients undergoing vaginal surgery using conventional techniques and group-b: include 100 patients undergoing vaginal surgery using tumescent anaesthesia (25 mol of $2 \%$ lignocaine and $.5 \mathrm{ml} \mathrm{eg}$. Adrenaline (1:1000 conc.) ease and duration of surgery, blood loss, hemodynamic changes during surgery were recorded and comparison drawn and analysed by statistical analysis. Results: In our study, time required for completion of surgery in group-a was 21-35 min as in group-b it was 36-50 min. More number of cases had blood loss $<100 \mathrm{ml}(28 \%)$ in group-a while in group b maximum number of cases had blood loss $>100 \mathrm{ml}(90 \% 0$. No significant change in mean blood pressure and heart rate between both groups $(\mathrm{p}>0.05)$.

Conclusion: Tumescent anaesthesia is on safe approach which reduces time of surgery and blood loss during surgery with no significant changes in haemodynamic variables.
\end{abstract}

Keywords: Tumescent anaesthesia, Vaginal hysterectomy, Hemodynamic changes

\section{INTRODUCTION}

Aquadissection is the use of hydraulic energy from pressurized fluid to aid in performance of surgical procedures. It uses direct infiltration of saline-based or similar solution to deliver lidocaine, epinephrine and other medication into the subcutaneous area or submucosal areas. ${ }^{1}$

The composition, concentration and total amount of aquadissection fluid infused are absolutely critical to a successful result. The presence of very diluted epinephrine, in the range of $1: 1,000,000$ causes vasoconstriction in the subcutaneous/submucosal tissue. This is turn has three important consequences: bleeding during and after the procedure is greatly decreased ${ }^{2}$ the local anaesthetic effect of lidocaine are prolonged, and the systemic absorption of lidocaine is delayed, permitting larger doses to be administered that could be safely done without the epinephrine.

Presence of normal saline simplifiers the surgery and makes the field bloodless by:

- Tissue beneath the mucosa is flooded with fluid. This compresses the vascular plane and creates a fluid tourniquet in injected areas.

- Fluid in sub-mucosa gives proper plane for dissection, resulting in fast surgery.

- Saline helps to separate the tissues, making the dissection less traumatic, so intra-operative and postoperative morbidity is reduced. 


\section{METHODS}

Present study was conducted in Department of Obst. \& Gynae., S.N. Medical College, Agra. Total 200 cases who underwent vaginal surgery were included in study. Cases were randomly divided into two groups:

Group-A Study group includes 100 cases who underwent vaginal surgery using aquadissection.

Group-B Control group includes 100 cases, who underwent vaginal surgery using conventional technique.

- $\quad$ Aquadissection has been used while performing vaginal hysterectomies ${ }^{3,4}$ and other gynaecological surgeries such as perineorrhaphy complete perineal tear repair, vaginoplasy, removal of vaginal and vulval cysts and case undering fistula repair.

- In both the groups surgery was done under spinal anaesthesia using 2.5 to $3 \mathrm{ml}$ of $0.5 \%$ bupivacaine.

- In study group, aquadissection was done by using solution, having $25 \mathrm{~mol}$ of $2 \%$ lignocaine and $0.5 \mathrm{ml}$ of adrenaline (1:1000 cone) in 500 $\mathrm{ml}$ of normal saline just before injection (This will give $0.1 \%$ concentration of xylocaine and 1:10,00,000 conc. Of adrenaline).

The following parameters were recorded for each patient in both the groups:

a) Ease of surgical dissection

b) Duration of surgery

c) Intra-operative blood loss

d) Need for intra-operative blood transfusion

e) Haemodynamic variables (heart rate, blood pressure, $\mathrm{SPO}_{2}$ and ECG) monitored continually if signs and symptoms of local anaesthesia.

Toxicity $^{5,6}$ - Tachycardia

- Rise in BP

- Fall in saturation

- ECG changes like arrhythmias etc.

Symptoms- Shivering, palpitation, chest pain, sweating and uneasiness, ECG changes like arrhythmias etc.

Use of tumescent anesthesia with adrenaline is contraindicated in case having-

- Hypertension

- $\quad$ Epilepsy

- H/o angina

- Patients on non-selective $\beta$-blockers

- It should not be given using anesthesia with halothane

To prevent lidocaine toxicity following factors were evaluated before using tumescent anesthesia-

- Liver function test

- History of any drug intake (to rule out drug interactions).

\section{RESULTS}

The main age in study group was 33.20 and in control group was 34.70 which was comparable in both the groups (Table 1).

Table 1: Distribution of cases according to age.

\begin{tabular}{|lllll|}
\hline \multirow{2}{*}{$\begin{array}{l}\text { Age (in } \\
\text { years) }\end{array}$} & \multicolumn{2}{l}{$\begin{array}{l}\text { Study group } \\
\text { (Group-A) }\end{array}$} & \multicolumn{2}{l|}{$\begin{array}{l}\text { Control group } \\
\text { (Group-B) }\end{array}$} \\
\cline { 2 - 5 } & No. & $\%$ & No. & $\%$ \\
\hline$<30$ & 12 & 12 & 12 & 12 \\
\hline $31-40$ & 50 & 50 & 44 & 44 \\
\hline $41-50$ & 32 & 32 & 36 & 36 \\
\hline$>50$ & 6 & 6 & 8 & 8 \\
\hline Total & 100 & 100 & 100 & 100 \\
\hline P value & 0.473 & & & \\
\hline
\end{tabular}

The time required for completion of surgery in Group-A was (21-35 min) whereas in Group B it was (36-50 min) (Table 2).

Table 2: Distribution of cases according to time taken for surgery.

\begin{tabular}{|lllll|}
\hline \multirow{2}{*}{$\begin{array}{l}\text { Time Taken } \\
\text { (in minutes) }\end{array}$} & \multicolumn{2}{l}{$\begin{array}{l}\text { Study group } \\
\text { (Group-A) }\end{array}$} & \multicolumn{2}{l|}{$\begin{array}{l}\text { Control group } \\
\text { (Group-B) }\end{array}$} \\
\cline { 2 - 5 }$<20$ & 12 & 12 & 2 & 2 \\
\hline $21-35$ & 68 & 68 & 36 & 36 \\
\hline $36-50$ & 16 & 16 & 52 & 5 \\
\hline$>50$ & 4 & 4 & 10 & 10 \\
\hline Mean & 29.30 & & 38.00 & \\
\hline SD & 9.786 & & 10.062 & \\
\hline P value & & & 0.001 & \\
\hline
\end{tabular}

Intraoperative blood loss assessment shows that in Group A more number of cases had blood loss $<100 \mathrm{ml}(28 \%)$ while in Group B maximum number of cases had blood loss > $100 \mathrm{ml}(90 \%)$ (Table 3).

As is evident from Table 4, in Group-A no surgical complications were seen. Only 2 cases (2\%) required blood transfusion and 2 cases $(2 \%)$ have tachycardia and rise in BP just after injection of TLA which was controlled within 5 minutes. Whereas in Group-B there were no case associated with tachycardia rise in BP, bladder and bowel injury 12 cases required post-operative blood transfusion. 
Table 3: Distribution of cases according to blood loss during surgery.

\begin{tabular}{|lllll|}
\hline $\begin{array}{l}\text { Amount of } \\
\text { blood loss } \\
\text { (in ml) }\end{array}$ & \multicolumn{2}{l}{$\begin{array}{l}\text { Study group } \\
\text { (Group-A) }\end{array}$} & $\begin{array}{l}\text { Control group } \\
\text { (Group-B) }\end{array}$ \\
\cline { 2 - 5 } & No. & $\%$ & No. & $\%$ \\
\hline$<50$ & 42 & 42 & - & - \\
\hline $51-100$ & 40 & 40 & 10 & 10 \\
\hline $101-150$ & 16 & 16 & 42 & 42 \\
\hline$>150$ & 2 & 2 & 48 & 48 \\
\hline Mean & 64.00 & 144.00 & \\
\hline SD & 39.102 & 33.00 & \\
\hline P value & 0.001 & & \\
\hline
\end{tabular}

Table 4: Distribution of cases according to intraoperative problem.

\begin{tabular}{|lll|lc|}
\hline $\begin{array}{l}\text { Type of intra } \\
\text { operative problem }\end{array}$ & \multicolumn{2}{l|}{$\begin{array}{l}\text { Study group } \\
\text { (Group-A) }\end{array}$} & \multicolumn{2}{|c|}{$\begin{array}{l}\text { Control group } \\
\text { (Group-B) }\end{array}$} \\
\cline { 2 - 5 } & No. & $\%$ & No. & $\%$ \\
\hline $\begin{array}{l}\text { Tachycardia (after } \\
\text { injection of TLA) }\end{array}$ & 2 & 2 & - & - \\
\hline $\begin{array}{l}\text { Rise in blood } \\
\text { pressure (after } \\
\text { injection of TLA) }\end{array}$ & 2 & 2 & - & - \\
\hline $\begin{array}{l}\text { Haemorrhage } \\
\text { (requiring blood } \\
\text { transfusion) }\end{array}$ & 2 & 2 & 12 & 12 \\
\hline $\begin{array}{l}\text { Need for } \\
\text { conversion to } \\
\text { abdominal route }\end{array}$ & - & - & 2 & 2 \\
\hline Bladder injury & - & - & - & - \\
\hline Bowel injury & - & - & - & - \\
\hline Chi-square & 1.778 & & \\
\hline P value & 0.182 & & \\
\hline
\end{tabular}

Table 5 outlines in the intraoperative hemodynamic variables (mean value of blood pressure) in Group-A cases mean blood presence pre-operatively was $114 / 72$ $\mathrm{mmHg}$, at the time of injection it was $118 / 78 \mathrm{mmHg}$. We had recorded blood pressure at the interval of every 15 min. during surgery. In most of the cases there was no significant change in blood pressure. In only 1 case $(1 \%)$ there was abrupt rise in blood pressure which was controlled within 5 minutes.

In group-B mean blood pressure pre-operatively was $112 / 74 \mathrm{mmHg}$, at the time of TLA injection it was $114 / 72$ $\mathrm{mmHg}$. $15 \mathrm{~min}$ blood pressure recordings show no significant change in blood pressure.

On reviewing the cases in both groups, it is evident that there was no significant change in the mean heart rate in both the groups (Table 6).

\section{DISCUSSION}

The term tumescent (meaning swollen) comes from the appearance of area immediately after injection before the medicine is absorbed in the surrounding tissues. Presence of large quantities of water in the facial spaces exerts mechanical pressure on the blood vessels thus acting as a compression and reduces intra-operative bleeding. Hence the name "water tourniquet".

Tumescent anesthesia is a new concept so very little literature is published on its use in vaginal surgeries. Therefore no studies are available for comparison.

Use of aquadissection technique for vaginal surgery significantly reduces duration of surgery ( $\mathrm{P}$ value $<0.01$ ). Also with the use of this technique intra-operative blood loss has progressively reduced over the years, so much so that as the present data projects, a single small sized sponge has been found to sufficient in majority of cases.

Table 5: Distribution of cases according to intra operative hemodynamic variables-mean value of blood pressure (Systolic/Diastolic).

\begin{tabular}{|lllllll|}
\hline & Pre-op & $\begin{array}{c}\text { After } \\
\text { TLA }\end{array}$ & \multicolumn{2}{c}{ During surgery } & & $\begin{array}{l}\text { Post } \\
\text { operative }\end{array}$ \\
\cline { 2 - 7 } & & & $\mathbf{1 5} \mathbf{~ m i n}$ & $\mathbf{3 0} \mathbf{~ m i n}$ & $\mathbf{4 5} \mathbf{m i n}$ & $<\mathbf{1 5}$ min \\
\hline Study group (Group-A) & $114 / 72$ & $118 / 78$ & $114 / 74$ & $112 / 76$ & $116 / 72$ & $112 / 74$ \\
\hline Control group (Group-B) & $112 / 74$ & $114 / 72$ & $112 / 76$ & $116 / 72$ & $114 / 74$ & $110 / 70$ \\
\hline Mean & $112 / 72$ & $116 / 74$ & $112 / 74$ & $114 / 74$ & $114 / 74$ & $112 / 72$ \\
\hline P value & 0.819 & 0.899 & 0.789 & 0.772 & 0.775 & 0.749 \\
\hline
\end{tabular}


Table 6: Distribution of cases according to intra operative hemodynamic variables-mean value of heart rate/min.

\begin{tabular}{|c|c|c|c|c|c|c|}
\hline & \multirow[t]{2}{*}{ Pre-op } & \multirow[t]{2}{*}{ After TLA } & \multicolumn{3}{|c|}{ During surgery } & \multirow{2}{*}{$\begin{array}{l}\text { Post operative } \\
<15 \text { min }\end{array}$} \\
\hline & & & $15 \mathrm{~min}$ & $30 \mathrm{~min}$ & $45 \mathrm{~min}$ & \\
\hline Study group (Group-A) & 74 & 78 & 72 & 76 & 80 & 84 \\
\hline Control group (Group-B) & 76 & 74 & 78 & 72 & 76 & 82 \\
\hline Mean & 75 & 76 & 76 & 74 & 78 & 83 \\
\hline$P$ value & 0.812 & 0.834 & 0.842 & 0.825 & 0.852 & 0.839 \\
\hline
\end{tabular}

With the introduction of tumescent anesthesia, as the blood loss during surgery is minimal, the incidence of intraoperative and postoperative blood transfusion is also minimized.

There was no significant change in mean blood pressure and mean heart rate between both the study and control groups before and after administration of tumescent anesthesia $(\mathrm{p}>0.05)$.

\section{CONCLUSION}

To conclude we can say that tumescent anesthesia is a safe approach which significantly reduces true time of surgery, minimizes intra-operative blood loss, with no significant change in intra-operative hemodynamic variables.

\section{REFERENCES}

1. Klein JA. Bupivacaine, prilocaine, and ropivacaine. In: Tumescent technique: tumescent anesthesia and microcannular liposuction. Mosby, St. Louis, MO;2000:179-183.
2. Rudolph H, De Jong. Tumescent Anesthesia: Lidocaine Dosing Dichotomy. International Journal of Cosmetic Surgery and Aesthetic Dermatology 2002;4:3-7.

3. Sheth SS. Vaginal hysterectomy. Best Practice and Research -Clinical Obstetrics and Gynecology. Edited by Prof. S. Arulkumaran, (Guest Editors R. Thakar \& I. Manyonda) USA. Elsevier Ltd. 2005; Vol. 19(3):307-32.

4. Sheth SS. The scope of vaginal hysterectomy. Eur J Obstet Gynecol Reprod Biol 2004;115:224-30.

5. Agarwal P. Safe methods for release of severe post burn contracture neck under tumescent local anaesthesia and ketamine. Indian $\mathrm{J}$ Plast Surg 2002;37:51-4.

6. Modstrom H, Stabg K. Plasma lignocaine levels and risk after liposuction with TA. Acta Anaesth Scandi 2005;49:1487-90.

DOI: $10.5455 / 2320-1770 . i j r \operatorname{cog} 20130923$

Cite this article as: Pathak A, Singh S, Goel M, Agrawal N. A comparative review of intraoperative hemodynamic changes in patients undergoing vaginal surgeries using tumescent anaesthesia vs conventional techniques. Int $\mathbf{J}$ Reprod Contracept Obstet Gynecol 2013;2:379-82. 